\title{
Diffusion Equilibrium for Ammonia in the Kidney of the Acidotic Dog*
}

\author{
William J. Stone, $\$$ Sula mita Balagura, $\S$ and Robert F. Pitts with the \\ TECH NICAL ASSISTNCE OF Linda M. ShuRLAND \\ (From The Department of Physiology, Cornell University Medical College, \\ New York)
}

\begin{abstract}
Inflow of preformed ammonia in arterial blood, renal production of ammonia, outflow of ammonia in renal venous blood, and urinary excretion of ammonia were measured during the infusion of ${ }^{15} \mathrm{NH}_{4} \mathrm{Cl}$ into one renal artery of dogs with chronic metabolic acidosis. Our results show that the specific activity of ammonia measured in the urine and that calculated in the renal pool agree within $95 \%$. Pool specific activity is obtained by dividing the rate of infusion of isotope by the pool turnover rate, i.e., the sum of the rate of ammonia output in the urine and that in renal venous blood. An average of $35 \%$ of urinary ammonia is derived from arterial ammonia in these experiments.

We conclude that ammonia is distributed evenly throughout all phases of the kidney within a period less than the transit time of blood through the kidney. Furthermore, from the proportion of urinary ammonia we found to be derived from preformed arterial ammonia (35\%), and from our previous demonstration that $73 \%$ of urinary ammonia derives from deamidation and/or deamination of plasma glutamine, alanine, glycine, and glutamate, we can account for all of the ammonia that leaves the kidney in renal venous blood and in urine.
\end{abstract}

\section{Introduction}

The thesis that the mechanism of renal secretion of ammonia is passive, nonionic diffusion was suggested in 1948 by Pitts (1) in explanation of the proportionality between urinary hydrogen ion concentration and the rate of excretion of ammonia. The free base, $\mathrm{NH}_{3}$, is lipid soluble, uncharged, and penetrates cell membranes readily, whereas the ammonium ion, $\mathrm{NH}_{4}^{+}$, is water-soluble, charged, and relatively nonpenetrating (2). Thus $\mathrm{NH}_{3}$, formed in tubular cells from precursors delivered in arterial blood, diffuses into acid

* Received for publication 15 May 1967 and in revised form 22 June 1967.

This study was supported by U. S. Public Health Service grants AM 10101-02 and HE 00814.

$\$$ Fellow of the New York Heart Association. Present address: William Beaumont Hospital, El Paso, Tex.

$\S$ Established Investigator of the American Heart Association. Address requests for reprints to Dr. Sulamita Ralagura, Department of Physiology, Cornell University Medical College, 1300 York Avenue, New York 10021. urine where it is trapped as nondiffusible $\mathrm{NH}_{4}^{+}$ ion. It likewise diffuses into peritubular blood and is removed from the kidney in venous blood (3). This concept has been developed on theoretical grounds by Orloff and Berliner (4) and by Milne, Scribner, and Crawford (5).

The first real evidence for nonionic diffusion of ammonia was provided by Balagura and Pitts (6) who showed by the Chinard technique that ammonia diffuses readily and rapidly in both directions across the tubular epithelium, from blood to urine and from urine to blood. Furthermore they observed that the direction of net diffusion is from the less acid to the more acid phase. Since these are the basic tenets of the thesis of nonionic diffusion, its reality was established. Supportive evidence has been provided by the studies of Sullivan and McVaugh (7), Fulgraff and Pitts (8), and Denis, Preuss, and Pitts (9). The latter investigators demonstrated that the $\mathrm{pNH}_{3}$ of renal venous blood closely approximates that of renal 
cortical cells, which suggests that the free base may attain diffusion equilibrium among all cortical phases (10).

The experiments reported in this paper provide evidence for this view and extend it to include all renal phases: blood, interstitial fluid, proximal and distal tubular cells, and proximal and distal tubular urine. They demonstrate that the ammonia of the kidney of the dog exists as a single, wellmixed pool. Preformed ammonia enters the pool in arterial blood and mixes with ammonia produced within tubular cells from a variety of precursors. Ammonia leaves the pool in renal venous blood and in urine. No significant amount of ammonia leaves the pool by other routes; i.e., synthesis of glutamate (11), urea (12), or glutamine ${ }^{1}$ from ammonia does not occur to any appreciable extent in the kidney of the dog.

Inflow of preformed ammonia in arterial blood, renal production of ammonia, outflow of ammonia in renal venous blood, and urinary excretion of ammonia were all measured during the infusion of ${ }^{15} \mathrm{NH}_{4} \mathrm{Cl}$ into one renal artery at known and constant rates. The dilution of ${ }^{15} \mathrm{~N}$ in the total ammonia pool was calculated and its dilution in urinary ammonia was measured. Calculated and measured values agreed within limits of experimental error. Thus the isotope distributes rapidly throughout all phases of the kidney in proportion to their ammonia contents and within a period less than the transit time of blood through the kidney.

\section{Methods}

Mongrel dogs of either sex, weighing 15 to $24 \mathrm{~kg}$, were given $10 \mathrm{~g}$ of ammonium chloride mixed with their food on each of the 3 days before an experiment. Under light pentobarbital anesthesia an intravenous infusion containing $5 \mathrm{~g}$ of creatinine, $1.0 \mathrm{~g}$ of sodium $p$-aminohippurate, and $21.5 \mathrm{~g}$ of $\mathrm{Na}_{2} \mathrm{SO}_{4} \cdot 10 \quad \mathrm{H}_{2} \mathrm{O}$ per liter was begun at a rate of $5 \mathrm{ml} / \mathrm{min}$. A radiopaque catheter was introduced into the left renal vein under fluoroscopic visualization. Each ureter was catheterized through a midline lower abdominal incision and the catheter tip advanced to the level of the renal pelvis. A No. 18 needle with a tight stylet was placed in the right femoral artery. Through a flank incision, a curved No. 26 needle was introduced into the left renal artery near its aortic origin. Either 2.0 or $10.0 \mu$ moles of ${ }^{15} \mathrm{NH}_{4} \mathrm{Cl}(96.3$ atoms \% excess) per $\mathrm{ml}$ of isotonic saline was infused into the renal artery at a constant rate of $0.96 \mathrm{ml} / \mathrm{min}$

${ }^{1}$ Lyon, M. I. and R. F. Pitts. Unpublished observations. throughout the course of an experiment. After a $20 \mathrm{~min}$ equilibration period, a series of $15-\mathrm{min}$ timed urine samples were collected separately from each kidney. At the midpoint of each urine collection, femoral arterial and renal venous blood samples were withdrawn into heparinized syringes. Blood for ammonia determinations was collected in lightly oiled syringes under $\mathrm{CO}_{2}$ and stored in ice.

Creatinine, $p$-aminohippurate, urinary ammonia, and ${ }^{15} \mathrm{~N}$ content of urinary ammonia were determined by previously described methods (13). Creatinine clearance was used as a measure of the glomerular filtration rate, and whole blood $p$-aminohippurate extraction as a measure of total renal blood flow. Urine $\mathrm{pH}$ was measured with a Radiometer-Copenhagen meter and a capillary glass electrode.

Renal venous and arterial whole blood ammonias were determined by a modification of the method of Mondzac, Ehrlich, and Seegmiller (14) for plasma ammonia. In a cold room, $5 \mathrm{ml}$ of whole blood was pipetted into $5 \mathrm{ml}$ of $20 \%$ trichloroacetic acid with constant mixing. After centrifugation and filtration, $2 \mathrm{ml}$ of filtrate was added to a tube containing $5 \mathrm{ml}$ of $\mathrm{NADH}$ solution (11-16 mg/100 ml) in phosphate buffer $\mathrm{pH} 7.40$ and $1 \mathrm{ml}$ of sodium $\alpha$-ketoglutarate $(1.752 \mathrm{~g} / 100 \mathrm{ml})$ in phosphate buffer $\mathrm{pH} 7.40$. The $\mathrm{pH}$ of the final mixture was 7.00 to 7.10. Glutamate dehydrogenase (Boehringer) was added and samples incubated for $20 \mathrm{~min}$ in a $37^{\circ} \mathrm{C}$ water bath. Appropriate blanks and ammonium chloride standards in $10 \%$ trichloroacetic acid were included. Three types of blanks were used: one containing the above solutions without enzyme, one with $2 \mathrm{ml}$ of $10 \%$ trichloroacetic acid instead of blood filtrate, and one in which NADH was omitted. All samples were read in a Beckman DU spectrophotometer at $340 \mathrm{~m} \mu$. Duplicate samples agreed within $\pm 10 \%$.

The experiment illustrated in Fig. 1 was the only one in which the procedure differed from that described above. An intravenous infusion containing $43.0 \mathrm{~g}$ of $\mathrm{Na}_{2} \mathrm{SO}_{4} \cdot 10$ $\mathrm{H}_{2} \mathrm{O}$ per liter was administered at a rate of $10 \mathrm{ml} / \mathrm{min}$ to insure a copious flow of acid urine; five urine samples were collected at 2-min intervals followed by four samples at 5 -min intervals after the start of ${ }^{15} \mathrm{NH}_{4} \mathrm{Cl}$ infusion into the renal artery.

\section{Results}

The time course of appearance of ammonia- ${ }^{15} \mathrm{~N}$ in the urine of an acidotic dog, after the start of a constant infusion of the isotope into one renal artery, is illustrated in Fig. 1. Some 6 min were required for the excretion of ${ }^{15} \mathrm{NH}_{4}{ }^{+}$to stabilize at approximately $60 \%$ of its rate of infusion. Catheter and pelvic dead space, turnover time of the renal pool of ammonia precursors, and, more importantly, a spectrum of nephron transit times account for this delay. Accordingly, in all subsequent experiments, an equilibration period of 


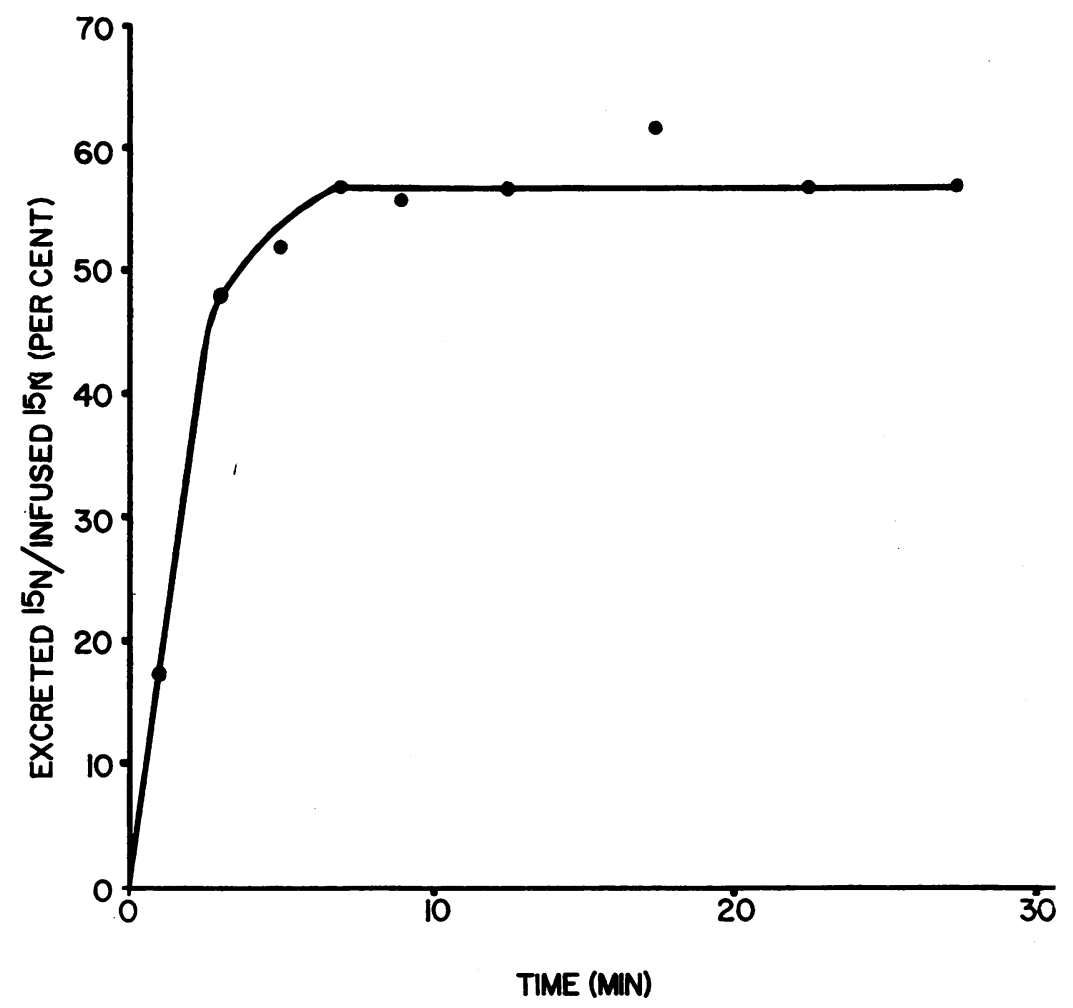

Fig. 1. Time course of appearance of AMMONIA- ${ }^{16} \mathrm{~N}$ IN THE URINE OF THE ACIDOTIC DOG AFTER THE START OF AN INFUSION OF THE LABELED COMPOUND INTO THE RENAL ARTERY.

20 min preceded the collection of the first urine specimen to ensure attainment of steady state conditions.

The ammonia pool of the kidney is no doubt small but turns over rapidly (15). The half-time of the turnover rate estimated from pool size in the dog kidney (15) and from pool turnover in our experiments is about $1 \mathrm{~min}$. As shown in Fig. 2, pool turnover is equal to the sum of the rates at which ammonia leaves the kidney in renal venous blood and is excreted in the urine. The major fraction of this ammonia is formed in the kidney from amino acid precursors extracted from blood; the minor fraction enters the kidney as preformed ammonia. If ${ }^{15} \mathrm{NH}_{4} \mathrm{Cl}$ is introduced into this pool at a known rate and if the pool is well mixed, measured specific activity should equal calculated specific activity. Since prohibitively large amounts of renal venous blood would be needed for isolation of the requisite amount of ammonia, specific activity has been measured only in urine.

Data from three representative experiments are summarized in Table I. The product of renal ve-

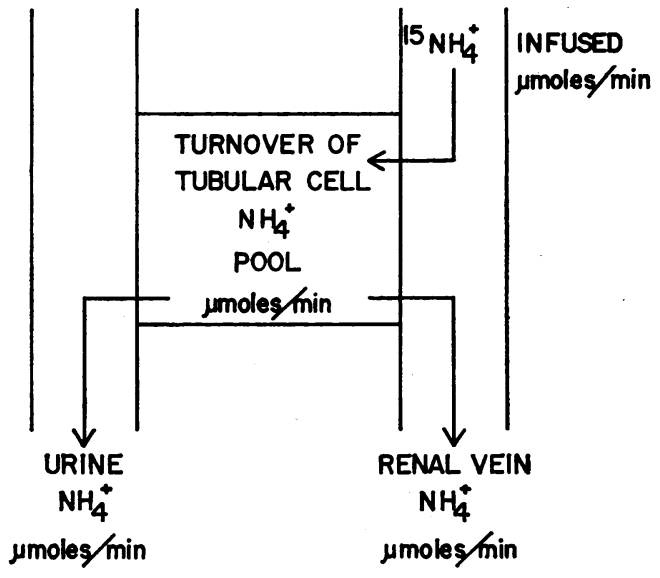

\section{FOR DIFFUSION EQUILIBRIUM :}

\section{MEASURED}

CALCULATED

$$
15_{N} / 14_{N}+{ }^{15} \mathrm{~N}=\frac{15 \mathrm{NH}_{4}^{+} \text {INFUSION RATE }}{\text { POOL TURNOVER RATE }}
$$

Fig. 2. Schematic REPREsentation of the RENAL AMMONIA POOL AND THE METHOD FOR ASSESSMENT OF DIFFUSION EQUILIBRIUM. 
TABLE I

Comparison between calculated and measured specific activities of ammonia in the kidney of the acidotic dog

\begin{tabular}{|c|c|c|c|c|c|c|c|c|c|}
\hline Period & VRBF & $\begin{array}{c}\text { Venous } \\
\text { ammonia }\end{array}$ & $\begin{array}{c}\text { Venous } \\
\text { load out }\end{array}$ & $\begin{array}{c}\text { Urinary } \\
\text { excretion }\end{array}$ & $\begin{array}{c}\text { Pool } \\
\text { turnover }\end{array}$ & ${ }^{16} \mathrm{~N}$ Infusion & Pool & Urine & $\frac{\text { Urine S.A }}{\text { Pool S.A. }}$ \\
\hline & $\mathrm{ml} / \mathrm{min}$ & $\mu m o l e s / m l$ & $\mu$ moles/min & $\begin{array}{r}\text { mmoles } / \min \\
\text { Exp }\end{array}$ & $\begin{array}{l}\text { umoles/min } \\
\text { eriment } 1\end{array}$ & umoles/min & S.A. & $\begin{array}{l}(\mathrm{L}-\mathrm{R}) \\
S . A .\end{array}$ & \\
\hline $\begin{array}{l}1 \\
2 \\
3 \\
4\end{array}$ & $\begin{array}{l}503 \\
365 \\
317 \\
279\end{array}$ & $\begin{array}{l}0.070 \\
0.098 \\
0.093 \\
0.094\end{array}$ & $\begin{array}{l}35.2 \\
35.8 \\
29.5 \\
26.3\end{array}$ & $\begin{array}{l}23.9 \\
26.2 \\
38.9 \\
38.6\end{array}$ & $\begin{array}{l}59.1 \\
62.0 \\
68.4 \\
64.9\end{array}$ & $\begin{array}{l}1.86 \\
1.86 \\
9.29 \\
9.29\end{array}$ & $\begin{array}{l}3.15 \\
3.00 \\
13.6 \\
14.3\end{array}$ & $\begin{array}{r}3.24 \\
3.19 \\
14.42 \\
15.11\end{array}$ & $\begin{array}{l}1.03 \\
1.06 \\
1.06 \\
1.06\end{array}$ \\
\hline \multicolumn{10}{|c|}{ Experiment 2} \\
\hline $\begin{array}{l}1 \\
2 \\
3 \\
4\end{array}$ & $\begin{array}{l}241 \\
245 \\
184 \\
202\end{array}$ & $\begin{array}{l}0.060 \\
0.059 \\
0.088 \\
0.085\end{array}$ & $\begin{array}{l}14.5 \\
14.5 \\
16.2 \\
17.2\end{array}$ & $\begin{array}{l}23.5 \\
25.3 \\
24.6 \\
29.5\end{array}$ & $\begin{array}{l}38.0 \\
39.8 \\
40.8 \\
46.7\end{array}$ & $\begin{array}{l}1.85 \\
1.85 \\
9.25 \\
9.25\end{array}$ & $\begin{array}{l}4.87 \\
4.65 \\
22.7 \\
19.8\end{array}$ & $\begin{array}{r}5.23 \\
5.48 \\
18.04 \\
17.89\end{array}$ & $\begin{array}{l}1.07 \\
1.18 \\
0.79 \\
0.90\end{array}$ \\
\hline \multicolumn{10}{|c|}{ Experiment 3} \\
\hline $\begin{array}{l}1 \\
2 \\
3 \\
4 \\
5 \\
6\end{array}$ & $\begin{array}{l}342 \\
294 \\
290 \\
328 \\
230 \\
191\end{array}$ & $\begin{array}{l}0.062 \\
0.059 \\
0.052 \\
0.062 \\
0.082 \\
0.089\end{array}$ & $\begin{array}{l}21.2 \\
17.4 \\
15.1 \\
20.4 \\
18.9 \\
17.0\end{array}$ & $\begin{array}{l}37.6 \\
37.7 \\
37.2 \\
40.0 \\
39.0 \\
41.3\end{array}$ & $\begin{array}{l}58.8 \\
55.1 \\
52.3 \\
60.4 \\
57.9 \\
58.3\end{array}$ & $\begin{array}{l}1.85 \\
1.85 \\
1.85 \\
9.25 \\
9.25 \\
9.25\end{array}$ & $\begin{array}{c}3.15 \\
3.36 \\
3.53 \\
15.3 \\
16.0 \\
15.9\end{array}$ & $\begin{array}{r}3.30 \\
3.35 \\
3.44 \\
15.39 \\
15.85 \\
15.91\end{array}$ & $\begin{array}{l}1.05 \\
1.00 \\
0.98 \\
1.00 \\
0.99 \\
1.00\end{array}$ \\
\hline
\end{tabular}

VRBF, venous renal blood outflow [calculated from arterial blood flow by the Wolf equation (16), minus urine flow, plus rate of intraarterial infusion]. S.A., specific activity (atoms $\%{ }^{15} \mathrm{~N}$ excess).

nous blood flow (16) and ammonia concentration equals the load of ammonia leaving the kidney in the renal vein. The product of urine flow and ammonia concentration equals the rate of excretion of ammonia. The sum of the two is equal to the pool turnover. In the first periods of each experiment, ${ }^{15} \mathrm{NH}_{4} \mathrm{Cl}$ was infused into the left renal artery at a low rate. In later periods, the rate of infusion was increased fivefold. Dividing the rate of infusion of isotope by the pool turnover rate yields the calculated pool specific activity. The measured specific activity of urine formed by the left kidney, corrected for recirculation, agreed with the calculated pool specific activity within experimental error.

The major error of these determinations is in the measurement of blood ammonia concentration, since the mean of duplicate determinations may differ as much as $\pm 20 \%$ from the probable true values. Much of the uncertainty is due to the variability in chromogens in filtrates of whole blood. However, errors are random, for recovery of the added ammonia, on an average, is complete. Experiments 1 and 3 were selected as representafive of five experiments which exhibited only small deviations from the mean ratio of urine specific activity/pool specific activity. Experi- ment 2 exhibited the maximum deviations from the mean. The mean ratio in 13 comparisons of measured urine specific activity/calculated pool specific activity at low rates of infusion of isotope was 0.96 ( $\pm 0.04 \mathrm{SE})$. The mean ratio in 12 comparisons at high rates of infusion of isotope was 0.94 $( \pm 0.04 \mathrm{SE})$. Thus a fivefold increase in rate of infusion of isotope did not alter completeness of mixing. Within limits this suggests that ammonia is distributed by passive processes of diffusion rather than by active transport.

\section{Discussion}

Previous studies from our laboratory have demonstrated that urinary ammonia is derived from its several plasma precursors in the following mean proportions: amide $\mathrm{N}$ of glutamine, $43.3 \%$; amino $\mathrm{N}$ of glutamine, $18.3 \%$; amino $\mathrm{N}$ of alanine, $5.71 \%$; amino $\mathrm{N}$ of glycine, $3.76 \%$; and amino $\mathrm{N}$ of glutamic acid, $1.88 \%$. The sum of the contributions of these several precursors to urinary ammonia is $73.0 \%(11,13,17)$. Our present work demonstrates that if $73 \%$ of the urinary ammonia is derived from these five precursors, exactly the same proportions of the ammonia added to renal venous blood must also be derived from them. In the past we had tacitly assumed this to 
be true without the direct experimental confirmation which this study provides. We had also assumed that the $27 \%$ of the ammonia added to renal venous blood and excreted in urine which is not accounted for by these five precursors is derived from the deamination of other circulating plasma amino acids. Actually this is not true. It is largely if not entirely derived from ammonia entering the kidney in arterial blood. Finally, we can now reinterpret our previous study (17) as indicating that virtually all of the ammonia formed in the kidney derives from plasma glutamine, alanine, giycine, and glutamate.

Data demonstrating this fact are summarized in Table II and are derived from two of the same experiments presented in part in Table $I$. The product of renal arterial inflow and arterial blood concentration of ammonia equals the perfused ammonia load entering the kidney. The perfused load plus the infused load equals the total arterial load. Dividing this total load into $\mu$ moles ${ }^{15} \mathrm{NH}_{4}{ }^{+}$ excess infused into the renal artery yields arterial specific activity. Dividing urine specific activity, corrected for recirculation, by arterial specific activity, and multiplying by 100 , yields the percentage of the urinary ammonia derived from arterial ammonia. The fact that isotopic ammonium chloride must be infused into one renal artery to determine the contribution of arterial ammonia to urinary ammonia excretion obviously increases that contribution. From the first we have recognized that the infusion of any ${ }^{15} \mathrm{~N}$-labeled precursor of ammonia into one renal artery similarly increases its contribution to urinary ammonia excretion at least to a minor degree. The mean contribution of arterial ammonia to urinary ammonia in the present experiments is $35 \%$ (range 23$48 \%$ ). Thus the five precursors plus arterial ammonia on an average account for $108 \%$ of the ammonia excreted in the urine and added to renal venous blood. The possible sources and direction of errors of estimation convince us that no other blood precursors normally contribute significantly to ammonia formation by the kidney of the acidotic dog. Indeed it is probable that the amide and amino nitrogens of glutamine account for more than $90 \%$ of the ammonia formed in the kidney and that all other precursors account for less than $10 \%$.

The experiments cited in this paper do not bear directly on the nature of the ammonia transport mechanism. However, on the basis of work described in the introduction, we accept nonionic diffusion as the major if not the only determinant of the magnitude and direction of transport. Indeed it would be difficult to visualize an active transport system which alone could account for equilibrium distribution of synthesized and preformed ammonia throughout a heterogeneous system of widely differing hydrogen ion concentrations such as the kidney. However, we are aware of no experiments which exclude a minor contribution of active transport to ammonia secretion (18).

TABLE II

Contribution of arterial ammonia to urinary ammoria

\begin{tabular}{|c|c|c|c|c|c|c|c|c|c|}
\hline Period & ARBF & $\begin{array}{c}\text { Arterial } \\
\text { ammonia }\end{array}$ & $\begin{array}{l}\text { Perfused } \\
\text { arterial } \\
\text { load }\end{array}$ & $\begin{array}{l}\text { Infused } \\
\text { arterial } \\
\text { load }\end{array}$ & $\begin{array}{c}\text { Total } \\
\text { arterial } \\
\text { load }\end{array}$ & 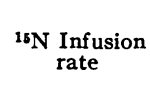 & Arterial & Urine & $\begin{array}{l}\text { Urine } \mathrm{NH}_{4} \\
\text { from } \\
\text { arterial } \mathrm{NH}_{4}\end{array}$ \\
\hline & $m l / \min$ & umoles $/ \mathrm{ml}$ & $\mu$ moles/min & $\begin{array}{r}\text { umoles } / \min \\
\text { Exp }\end{array}$ & $\begin{array}{l}\text { umoles/min } \\
\text { eriment } 1\end{array}$ & $\mu m o l e s / m i n$ & S.A. & $\begin{array}{l}(\mathrm{L}-\mathrm{R}) \\
S . A .\end{array}$ & $\%$ \\
\hline $\begin{array}{l}1 \\
2 \\
3 \\
4\end{array}$ & $\begin{array}{l}505 \\
367 \\
319 \\
281\end{array}$ & $\begin{array}{l}0.047 \\
0.063 \\
0.066 \\
0.065\end{array}$ & $\begin{array}{l}23.8 \\
23.1 \\
21.1 \\
18.3\end{array}$ & $\begin{array}{l}1.93 \\
1.93 \\
9.65 \\
9.65\end{array}$ & $\begin{array}{l}25.7 \\
25.0 \\
30.8 \\
27.9\end{array}$ & $\begin{array}{l}1.86 \\
1.86 \\
9.29 \\
9.29\end{array}$ & $\begin{array}{l}7.24 \\
7.44 \\
30.2 \\
33.3\end{array}$ & $\begin{array}{r}3.24 \\
3.19 \\
14.42 \\
15.11\end{array}$ & $\begin{array}{l}44.8 \\
42.9 \\
47.8 \\
45.4\end{array}$ \\
\hline \multicolumn{10}{|c|}{ Experiment 2} \\
\hline $\begin{array}{l}1 \\
2 \\
3 \\
4\end{array}$ & $\begin{array}{l}241 \\
245 \\
184 \\
202\end{array}$ & $\begin{array}{l}0.042 \\
0.036 \\
0.056 \\
0.042\end{array}$ & \begin{tabular}{r|}
10.1 \\
8.8 \\
10.3 \\
8.5
\end{tabular} & $\begin{array}{l}1.92 \\
1.92 \\
9.61 \\
9.61\end{array}$ & $\begin{array}{l}12.0 \\
10.7 \\
19.9 \\
18.1\end{array}$ & $\begin{array}{l}1.85 \\
1.85 \\
9.25 \\
9.25\end{array}$ & $\begin{array}{l}15.4 \\
17.2 \\
46.5 \\
51.2\end{array}$ & $\begin{array}{r}5.23 \\
5.48 \\
18.04 \\
17.89\end{array}$ & $\begin{array}{l}34.0 \\
31.9 \\
38.8 \\
34.9\end{array}$ \\
\hline
\end{tabular}
excess).

ARBF, arterial renal blood inflow (calculated by the Wolf equation (16)); S.A., specific activity (atoms $\%{ }^{15} \mathrm{~N}$ 


\section{References}

1. Pitts, R. F. 1948. Renal excretion of acid. Federation Proc. 7 : 418.

2. Jacobs, M. H. 1940 . Some aspects of cell permeability to weak electrolytes. Cold Spring Harbor Symposia Quant. Biol. 8 : 30.

3. Nash, T. P., and S. R. Benedict. 1921. The ammonia content of the blood, and its bearing on the mechanism of acid neutralization in the animal organism. J. Biol. Chem. $48: 463$.

4. Orloff, J., and R. W. Berliner. 1956. The mechanism of the excretion of ammonia in the dog. $J$. Clin. Invest. 35 : 223.

5. Milne, M. D., B. H. Scribner, and M. A. Crawford. 1958. Nonionic diffusion and the excretion of weak acids and bases. Am. J. Med. 24: 709.

6. Balagura, S., and R. F. Pitts. 1962. Excretion of ammonia injected into renal artery. $A m$. J. Physiol. 203 : 11.

7. Sullivan, L. P., and M. McVaugh. 1963. Effect of rapid and transitory changes in blood and urine $\mathrm{pH}$ on ammonia excretion. Am. J. Physiol. 204 : 1077.

8. Fulgraff, G., and R. F. Pitts. 1965. Kinetics of ammonia production and excretion in the acidotic dog. Am. J. Physiol. 209: 1206.

9. Denis, G., H. Preuss, and R. F. Pitts. 1964. The
$\mathrm{pNH}_{3}$ of renal tubular cells. J. Clin. Invest. 43: 571.

10. Pitts, R. F. 1964. Renal production and excretion of ammonia. Am. J. Med. 36: 720.

11. Pitts, R. F., and W. J. Stone. 1967. Renal metabolism of alamine. J. Clin. Invest. $46: 530$.

12. Van Slyke, D. D., R. A. Phillips, P. B. Hamilton, R. M. Archibald, P. H. Futcher, and A. Hiller. 1943. Glutamine as a source material of urinary ammonia. J. Biol. Chem. 150: 481.

13. Pitts, R. F., L. A. Pilkington, and J. C. M. DeHaas. 1965. ${ }^{15} \mathrm{~N}$ tracer studies on the origin of urinary ammonia in the acidotic dog, with notes on the enzymatic synthesis of labeled glutamic acid and glutamines. J. Clin. Invest. 44: 731 .

14. Mondzac, A., G. E. Ehrlich, and J. E. Seegmiller. 1965. An enzymatic determination of ammonia in biological fluids. J. Lab. Clin. Med. $66: 526$.

15. Robinson, R. R., and E. E. Owen. 1965. Intrarenal distribution of ammonia during diuresis and antidiuresis. Am. J. Physiol. 208: 1129.

16. Wolf, A. V. 1941. Total renal blood flow at any urine flow or extraction fraction. Am. J. Physiol. 133 : P 496.

17. Pitts, R. F. 1966. The renal metabolism of ammonia. Physiologist. 9: 97.

18. Weiner, I. M., and G. H. Mudge. 1964. Renal tubular mechanisms for excretion of organic acids and bases. Am. J. Med. 36: 743 . 